\title{
Geomechanical Characterization of Sandstones Cliffs of Segou (Senegal, West Africa) in the Madina Kouta Basin
}

\author{
Déthié Sarr $^{1}$, Meissa Fall ${ }^{1}$, Papa Malick Ngom ${ }^{2}$, Mapathé Ndiaye ${ }^{1}$, Cheikh H. Kane ${ }^{1}$, Makhaly Ba ${ }^{1}$ \\ ${ }^{1}$ Laboratoire de Mécanique et Modélisation-UFR Sciences de l’Ingénieur, Université de Thiès, Thiès, Sénégal \\ ${ }^{2}$ Département de Géologie, FST-UCAD, Université Cheikh Anta Diop de Dakar, Dakar, Sénégal \\ Email: dethie.sarr@ufrsi-thies.sn
}

Received October 22, 2011; revised November 23, 2011; accepted December 26, 2011

\begin{abstract}
This work presents the behavior of Segou sandstones in the laboratory and in the field conditions. Four types of sandstone are collected in the northern part of the Madina Kouta basin (eastern Senegal). These types of specimens are the white sandstones, the red sandstones, the purple sandstones and the sandstones with intercalation of pelites. Uniaxial tests are carried out on these specimens of sandstones. The Young Moduli (E) and the Uniaxial Compression Strengths $\left(R_{c}\right)$ are higher for the white sandstone. Values of the mechanical parameters decrease slightly for red sandstones due to an increase of the amount of pelites in the composition of the rock. Decrease of mechanical parameters is more important for the purple facies due to an important network of fractures. The facies with weaker characteristics corresponds to the sandstones with intercalation of pelites. This is due to the soft nature of the pelites. The slope stability of the Cliff sides depends also on to these characteristics.
\end{abstract}

Keywords: Unconfined Compression Test-Uniaxial Compression Strength (UCT, $\mathrm{R}_{\mathrm{c}}$ ); JRC (Joint Roughness Coefficient), Young Modulus (E); Roughness; Segou-Madina Kouta Basin; Discontinuities; Dihedral; Slope; Cliff

\section{Introduction}

In eastern Senegal, Upper Proterozoic sedimentary rocks constitute the Segou-Madina Kouta basin. The formations of this area outcrop like Cliffs along the southern border of Senegal. Because of this geomorphology, the traffic is very difficult. To reduce this difficulty, it becomes necessary to adapt this domain to new technology. For that, understanding of mechanical behavior of rocks becomes a priority. In this basin, Sandstone is the facies which is most represented. It corresponds to the Cliff along the border between Senegal and Guinea. So, tests will be done on four facies of this kind of rock. The four facies can be identified by their colors depending on the composition of the rock. The four facies are red sandstone, white sandstone, purplish sandstones and sandstone with intercalated pelites. These facies are characteristic of the all sandstones described in the basin of Segou-Madina Kouta. Geomechanical studies must be performed on the sandstone cliff between Senegal and Guinea. This cliff contains important fracturations network. Some fractures can be observed directly in the field but for others, microscopic studies must be done. In this paper, we will correlate mechanical properties to mineralogical and microstructural composition of the rocks. At least, analysis of stability of this Cliff will be done using the stereographic method.

\section{Geological and Geographical Contexts}

Proterozoic formations are located in the far south east of Senegal (Figure 1). This area is crossed by the Gambia and the Faleme rivers (Senegal Rivers flowing). Its climate is soudano-sahelian. Lower Proterozoic formations of Senegal outcrop in this area, between Senegal and Guinea and correspond to the Segou-Madina Kouta basin. This basin is limited on the north side by volcanic formations of Kedougou-Kenieba inlier, on the south side by the Man ridge, on the west side by the Bassarides and the Rokellides and on the east by the Basin of Taoudini. The Basin of Segou-Madina Kouta consists of two super groups:

- The supergroup I consists of the Segou group and the Madina Kouta group (Figure 2). It is subdivided into two formations [1-6]. The Pelel formation consists of sandstones and pelites rested on to conglomerates. The formation of Dindifelo consists of three members: $\mathrm{DF}_{\mathrm{I}}$ (where sandstones alternate with pelites), $\mathrm{DF}_{\mathrm{II}}$ (which represents the cliff and consists of two members of sandstones with intercalated pelites and where dimensions of layers decrease with the elevation). Finally, $\mathrm{DF}_{\mathrm{III}}$ consists of ruiniform sand- 
stones. The formation of Fongolembi with limestone with intercalates claystones. The formation of Kanta consists of fine and medium sandstones. In the formation of Dira, we have sandstone associate with shale and pelites.

- The supergroup II is composed by the formation of Hassanah Diallo and the formation of Nandoumari. The Hassanah Diallo formation consists of Eocambrian tillite associated to sandstone. The Nandoumari formation consists of three members. The Tanague member with quartz-arenite, the Bowal member with dolomites and the Fougon member with Cherts and pelites.

\section{Geological Characterization of the Cliff}

The geological data are obtained in the sector from Walidiala to Yamoussa. In this domain, we have sandstones alternated with pelites. In Tanague, the beds of pelites are decimetric to metric. The beds of sandstone are centimetric (Figure 3).

The cliff in the border between Senegal and The Republic of Guinea consists of sandstones alternating with pelites. Sandstones form centimetric to metric beds while pelites are centimetric to subordinate or absent (Figure 4). It appears like two members (Member 1 and Member 2). The member 1 is characterized by an alternance of centimetric to decimetric beds of sandstone with intercalation of pelites. The member 2 constitutes the Cliff along the boundary between Senegal and Guinea (Conakry).

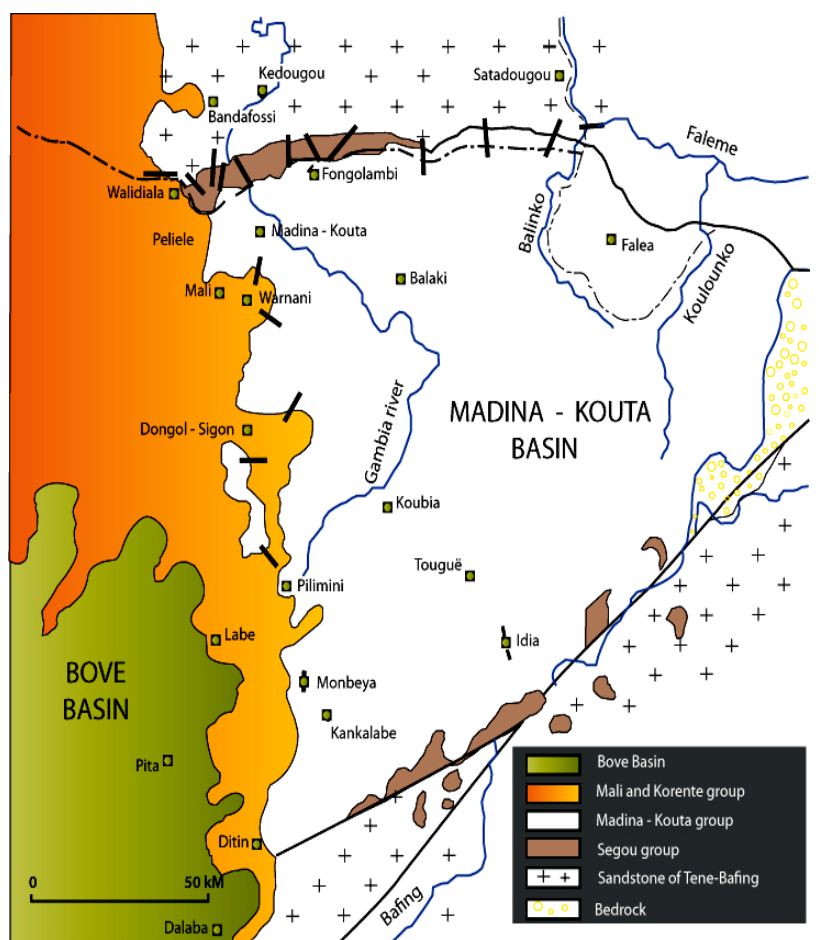

Figure 1. Geological map of Segou-Madina Kouta Basin [1].

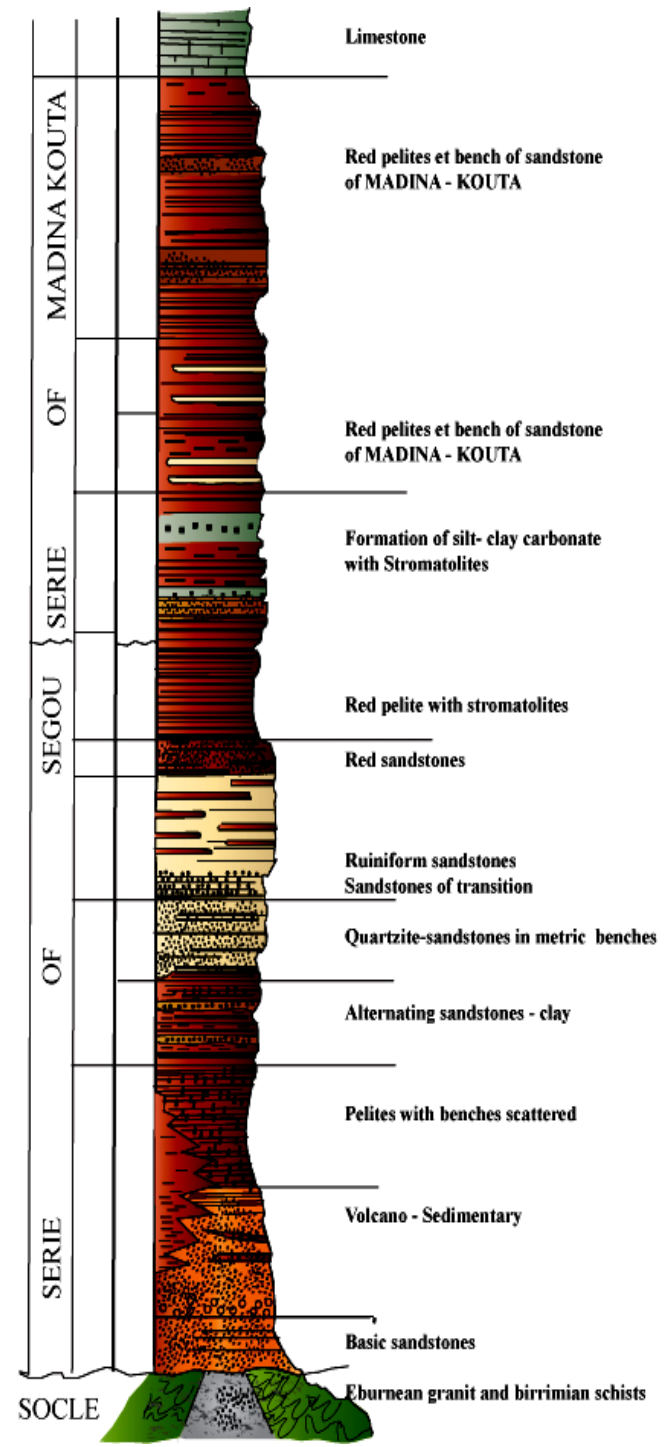

Figure 2. Lithostratigraphy of Segou-Madina Kouta basin [5].

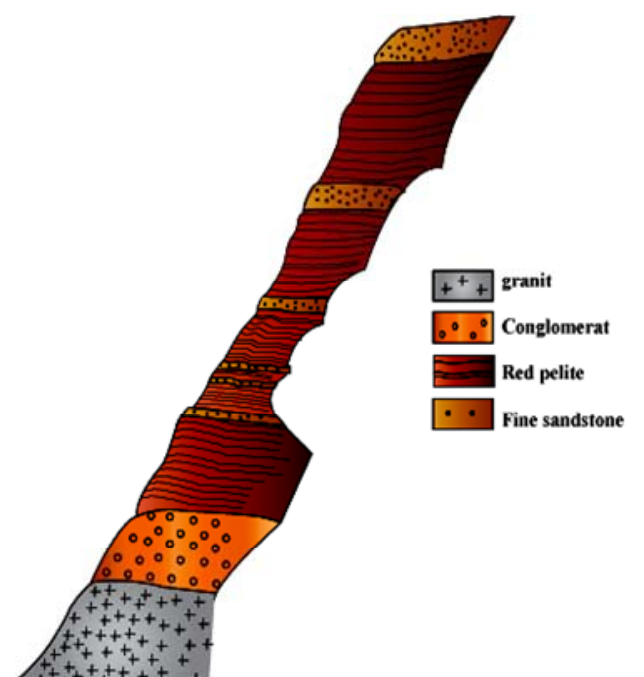

Figure 3. Lithostratigraphy of Tanague. 


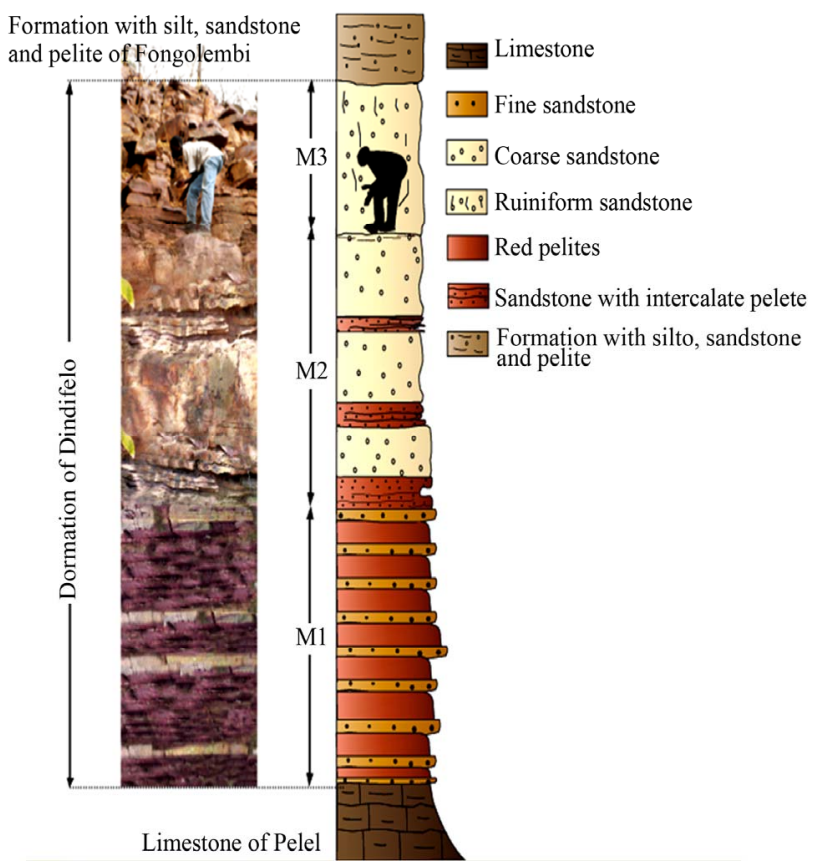

Figure 4. Lithostratigraphy of the formation of Dindifelo.

This second member consists of two terms. The term A is composed of centimetric beds of sandstones with intercalated pelites. The term B is composed of decimetric to metric beds where pelites are subordinate or absent.

\section{Mechanical Characterization}

\subsection{Structural Data}

Three directions of fractures characterize this area. These directions are the NE-SW, the ESE-WNW and ENEWSW. Fractures are represented by cracks and faults.
These fractures show high dips (Figures 5-7). Because of this fact, they show pole con centration at NW-SE, WNW-ESE and NNE-SSW for the side between Dindifelo and Pelel. For the side between Dindifelo and Segou, pole concentrations vary slightly and are NNW, NE and ENE. These discontinuities show high dip angle (Figures 6 and 7).

\subsection{JRC, Spacing, Frequencies and Opening of Discontinuities}

The JRC (Joint Roughness Coefficient) is estimated by comparing the profile of the discontinuities with Barton and Choubey charter [7-11] for laboratory data. The JRC in the field is given by the following equation:

$$
J R C_{n}=J R C_{0}\left(\frac{L_{n}}{L_{0}}\right)^{-0.02 J R C_{0}}
$$

$J R C_{n}$ is the exact value, $\left(J R C_{0}\right)$ the reference value, $\left(L_{n}\right)$ the measured length and $\left(L_{0}\right)$ the reference length

Drawing a scanline and measuring the distance between different discontinuities define the spacing between discontinuities. From these data, we deduce the spacing as the average distance between discontinuities. Frequency $(f)$ is defined by the following function where $X$ is the average distance:

$$
f=1 / X
$$

Given the range of these JRC (Table 1), we can see that we have smooth to slightly rough discontinuities. This more or less smooth aspect of the discontinuities confer them remarkable power of shear. So a small tangential strength can caused displacement of joint. For surfaces of stratification (Table 2), the range of JRC

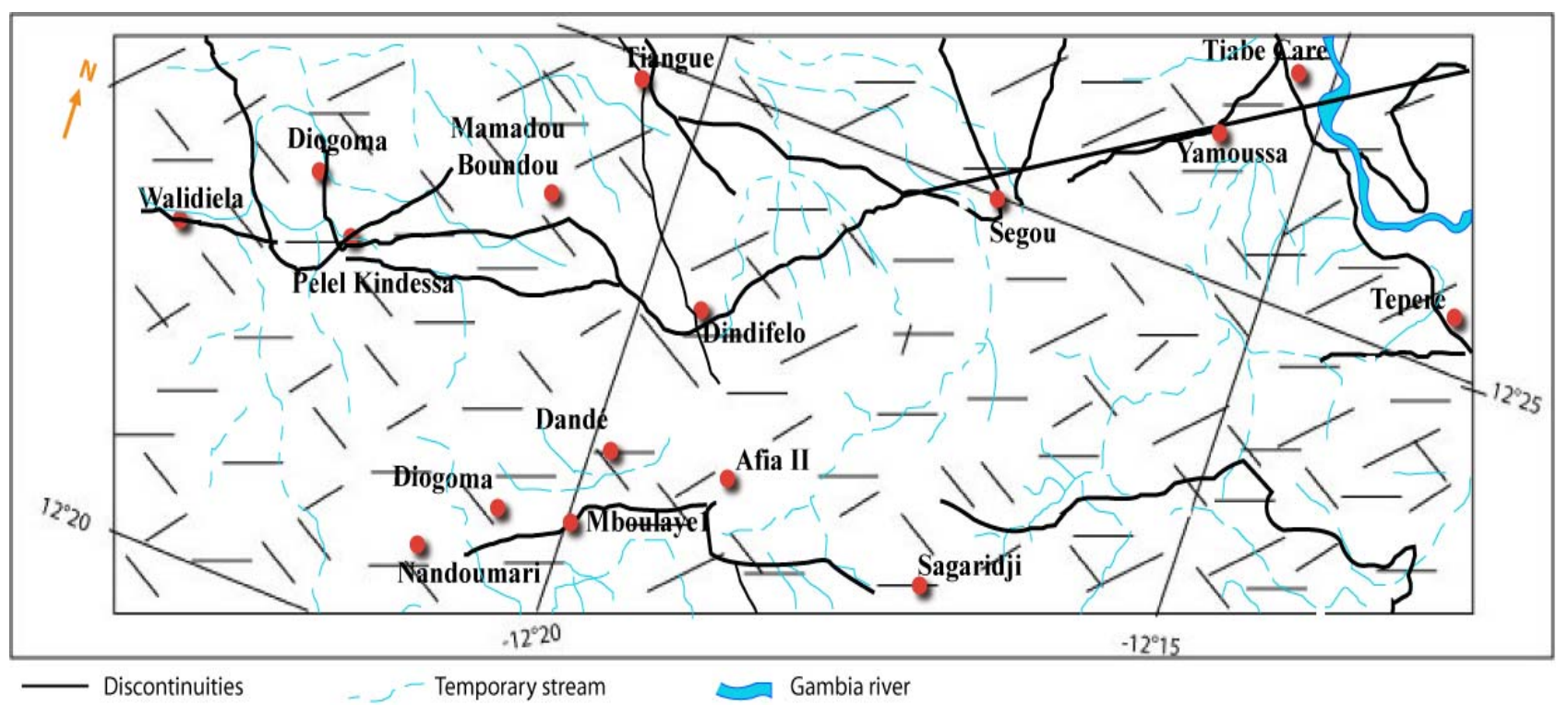

Figure 5. Map of lineaments of the sector from Walidiala to Tempere. 


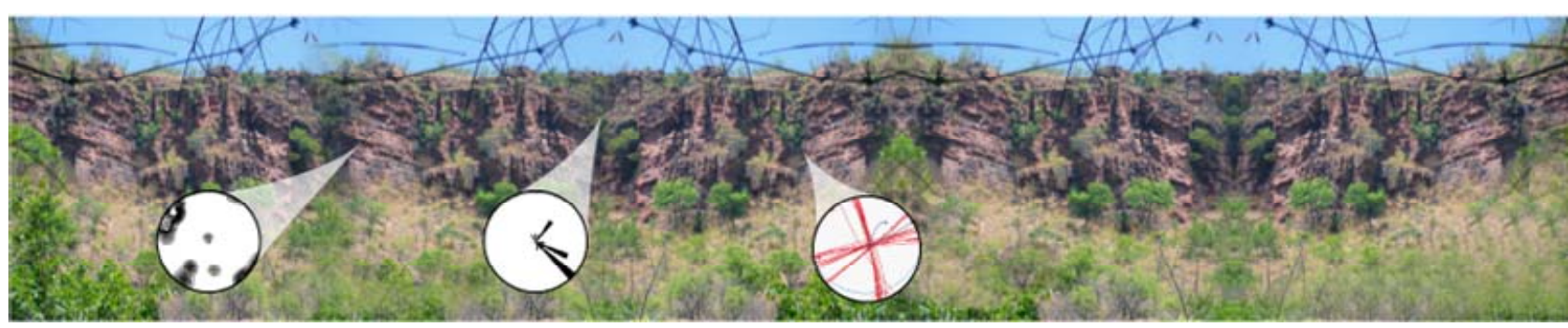

Figure 6. Panoramic view of Cliff between Dindifelo to Pelel.

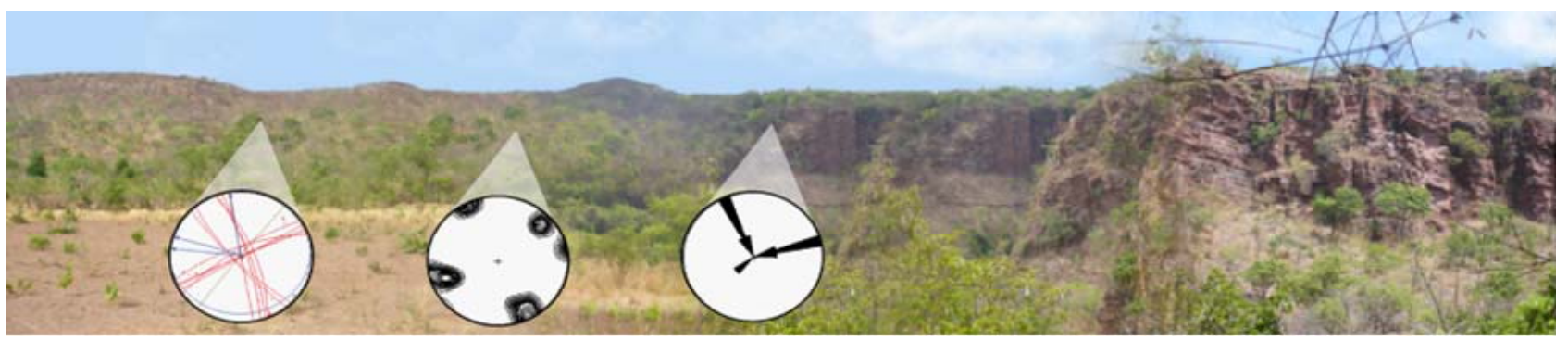

Figure 7. Panoramic view of the cliff between Dindifelo and Segou.

Table 1. JRC values for sandstone fractures.

\begin{tabular}{cccccccc}
\hline $\boldsymbol{L}_{\mathbf{0}}$ (Length in charter $(\mathrm{cm})$ ) & 5 & 5 & 5 & 5 & 5 & 5 & 5 \\
\hline $\boldsymbol{L}_{\boldsymbol{n}}$ (length in the field $(\mathrm{cm})$ ) & 75 & 50 & 45 & 205 & 150 & 100 & 20 \\
$\boldsymbol{J}_{\boldsymbol{R}}$ (JRC in the charter) & 1 & 1.5 & 1.5 & 1.5 & 1.5 & 0.8 & 1 \\
$\boldsymbol{J R C}_{\boldsymbol{n}}$ (Calculated $\left.J R C\right)$ & 0.947 & 1.399 & 1.404 & 1.341 & 1.354 & 0.762 & 0.972 \\
\hline
\end{tabular}

Table 2. JRC values for surface of stratification.

\begin{tabular}{|c|c|c|c|c|c|c|c|c|c|c|c|}
\hline \multicolumn{3}{|c|}{$\boldsymbol{L}_{0}($ Length in charter $(\mathrm{cm}))$} & 10 & 10 & \multicolumn{2}{|c|}{10} & 10 & 10 & \multicolumn{2}{|c|}{10} & 10 \\
\hline \multicolumn{3}{|c|}{$\mathbf{L}_{n}($ length in the field $(\mathrm{cm}))$} & 100 & 48 & \multicolumn{2}{|c|}{30} & 37 & 30 & \multicolumn{2}{|c|}{95} & 10 \\
\hline \multicolumn{3}{|c|}{$J_{R} \mathbf{C}_{0}(J R C$ in the charter $)$} & 10 & 15 & \multicolumn{2}{|c|}{17} & 15 & 17 & \multicolumn{2}{|c|}{15} & 16 \\
\hline \multicolumn{3}{|c|}{$J \boldsymbol{R} \boldsymbol{C}_{\mathbf{n}}($ Calculated $J R C)$} & 6.309 & 9.369 & \multicolumn{2}{|c|}{11.701} & 10.130 & 11.701 & \multicolumn{2}{|c|}{7.6341} & 16 \\
\hline $\boldsymbol{L}_{0}(\mathrm{~cm})$ & 10 & 10 & 10 & 10 & 10 & 10 & 10 & 10 & 10 & 10 & 10 \\
\hline $\boldsymbol{L}_{n}(\mathrm{~cm})$ & 14 & 13 & 17 & 20 & 35 & 120 & 95 & 95 & 70 & 50 & 25 \\
\hline$J R C_{0}$ & 16 & 17 & 17 & 11 & 16 & 8 & 1 & 1 & 0.5 & 0.2 & 0.2 \\
\hline$J R C_{\mathrm{n}}$ & 14.366 & 15.549 & 14.193 & 9.444 & 10.716 & 5.375 & 0.956 & 0.956 & 0.490 & 0.199 & 0.199 \\
\hline
\end{tabular}

shows values with very remarkable differences. Values are less than 1 for the surfaces of pelites beds and can reach some values around 16 .

\subsection{Laboratory Data}

\subsubsection{Petrographic Data}

Analysis of preparations of sandstone shows that they are in the major part made up by quartz minerals and small portion of pelites. There are also fragments of rock represented by fragments of granits. So we deduce from this composition that the sandstone has the granit of the socle as protolite. All the four facies have the same composition. But, red ones (Figure 8(a)) and white ones (Figure 8(b)) are must own. The sandstones with intercalation of pelites (Figure 8(c)) are characterized by the important part of pelites and contain also some oxides. The purple sandstones are characterized by their fractures network (Figure 8(d)).

Analyses of JRC show that microdiscontinuities are smooth (Table 3). Their JRC are lower than one (1). This characteristic causes in some part a low supported charging of the rock. For the contacts of minerals, JRC shows large intervals of values (Table 4). So, these values vary 


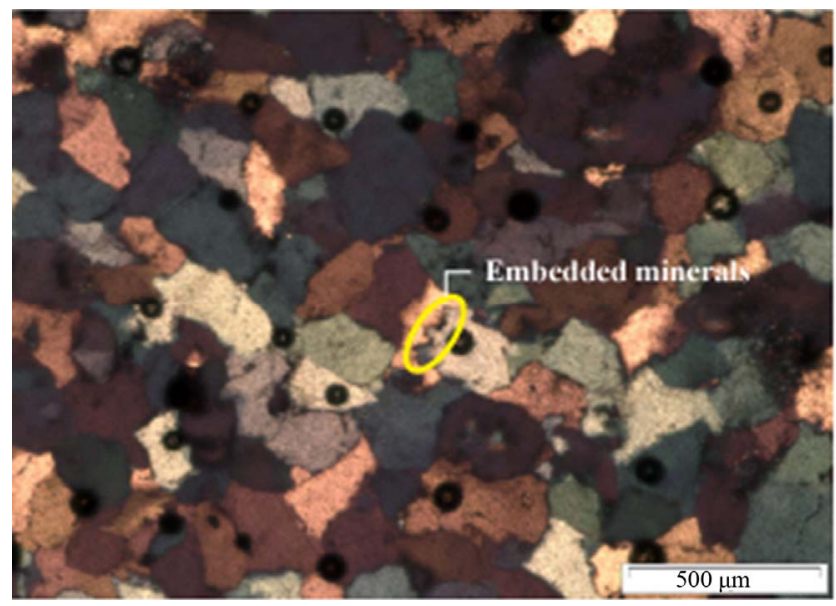

(a)

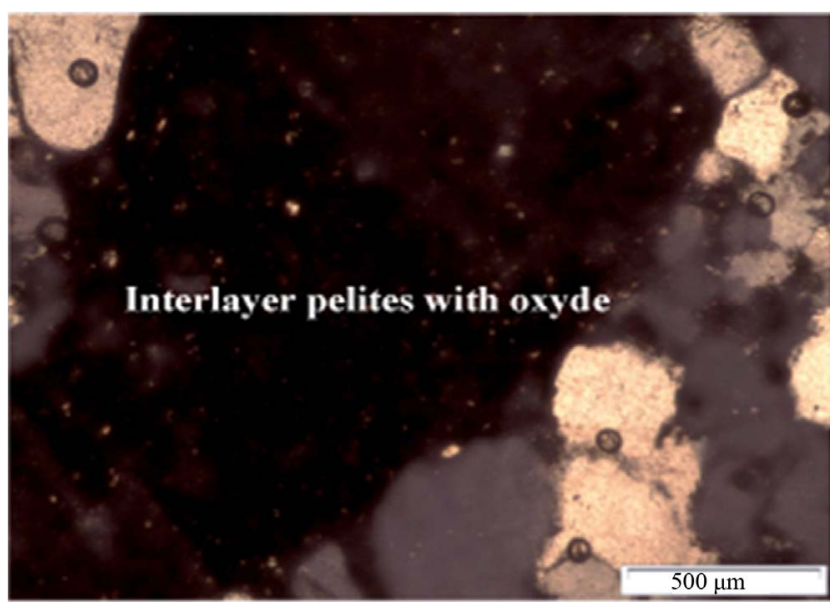

(c)

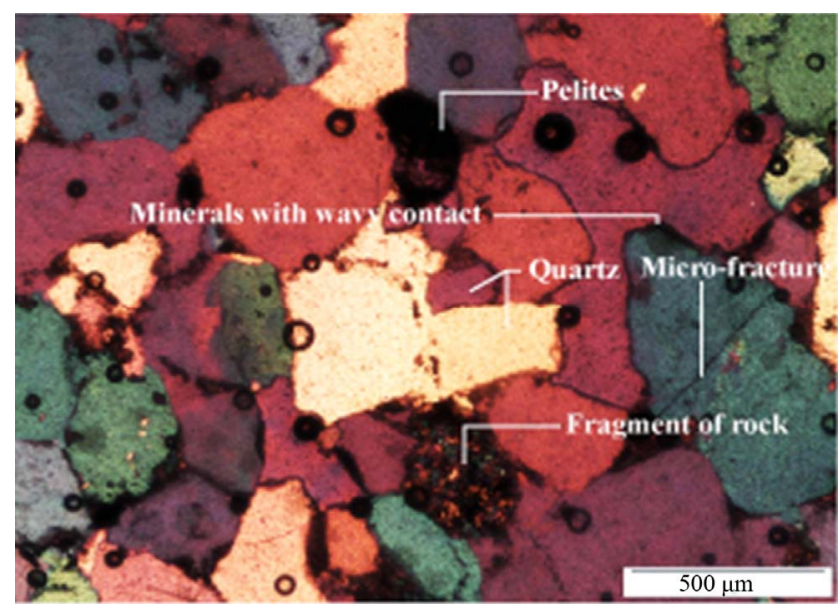

(b)

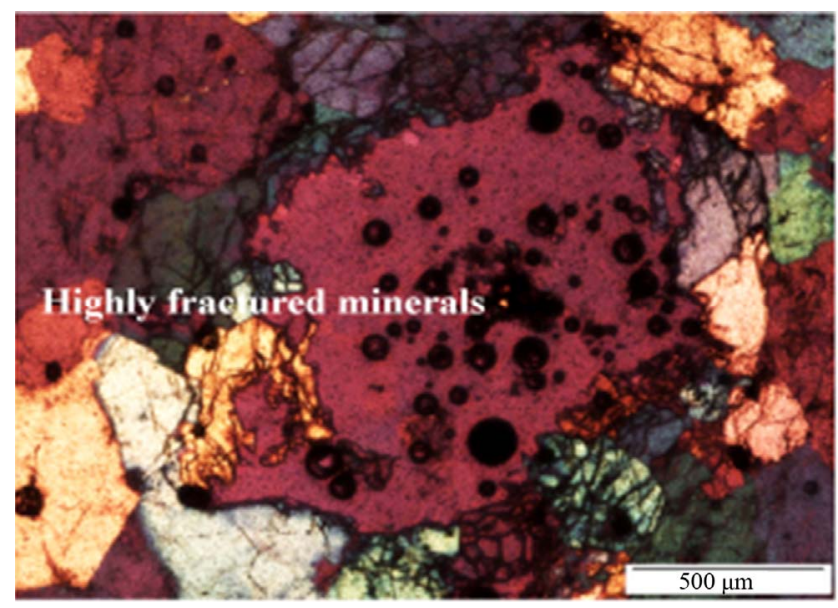

(d)

Figure 8. Preparation of sandstones. (a) Red sandstones; (b) White sandstones; (c) Sandstones with intercalation of pelites; (d) Purple sandstones

Table 3. JRC values for microfractures.

\begin{tabular}{lccccccccc}
\hline $\boldsymbol{L}_{\mathbf{0}}$ (Length in the charter $(\mathrm{cm})$ ) & 5 & 5 & 5 & 5 & 5 & 5 & 5 & 5 & 5 \\
\hline $\boldsymbol{L}_{\boldsymbol{n}}$ (length in the preparation $(\mathrm{cm})$ & 0.02 & 0.3 & 1 & 0.01 & 0.009 & 0.1 & 0.07 & 1.5 & 0.04 \\
$\boldsymbol{J R C}_{\boldsymbol{0}}(\mathrm{JRC}$ in the charter) & 0.5 & 0.6 & 0.5 & 0.5 & 0.7 & 0.9 & 0.6 & 0.8 & 0.5 \\
$\boldsymbol{J R C}_{\boldsymbol{n}}$ (Calculate JRC) & 0.528 & 0.620 & 0.508 & 0.532 & 0.764 & 0.965 & 0.631 & 0.815 & 0.525 \\
\hline
\end{tabular}

Table 4. JRC values of contacts between minerals.

\begin{tabular}{lccccccccc}
\hline $\boldsymbol{L}_{\mathbf{0}}$ (Length in the charter $(\mathrm{cm})$ ) & 5 & 5 & 5 & 5 & 5 & 5 & 5 & 5 & 5 \\
\hline $\boldsymbol{L}_{\boldsymbol{n}}$ (length in the preparation $(\mathrm{cm})$ & 0.03 & 0.201 & 0.015 & 0.02 & 0.06 & 0.105 & 0.06 & 0.014 & 1.05 \\
$\boldsymbol{J R C}_{\boldsymbol{0}}$ (JRC in the charter) & 6.7 & 8 & 6.5 & 3 & 1 & 0.5 & 0.5 & 6.5 & 10 \\
$\boldsymbol{J R C}_{\boldsymbol{n}}$ (Calculate JRC) & 13.298 & 13.378 & 13.832 & 4.178 & 1.092 & 0.519 & 0.523 & 13.956 & 13.663 \\
\hline
\end{tabular}

between 0.5 to 14 . Those values correspond to smooth to rough contacts.

\subsubsection{Laboratory Data}

Mechanical tests are carried on different facies of sandstones. The stress-strain curves (Figure 9) of the sand- stones showthat mechanical parameters of this rock are different from one specimen to another one. The values of parameters deduced to uni-axial test are represented in the following table (Table 5). Those parameters correspond to the Young Moduli (E) and the Uni-axial compressive strengths $\left(\mathrm{R}_{\mathrm{c}}\right)$. 

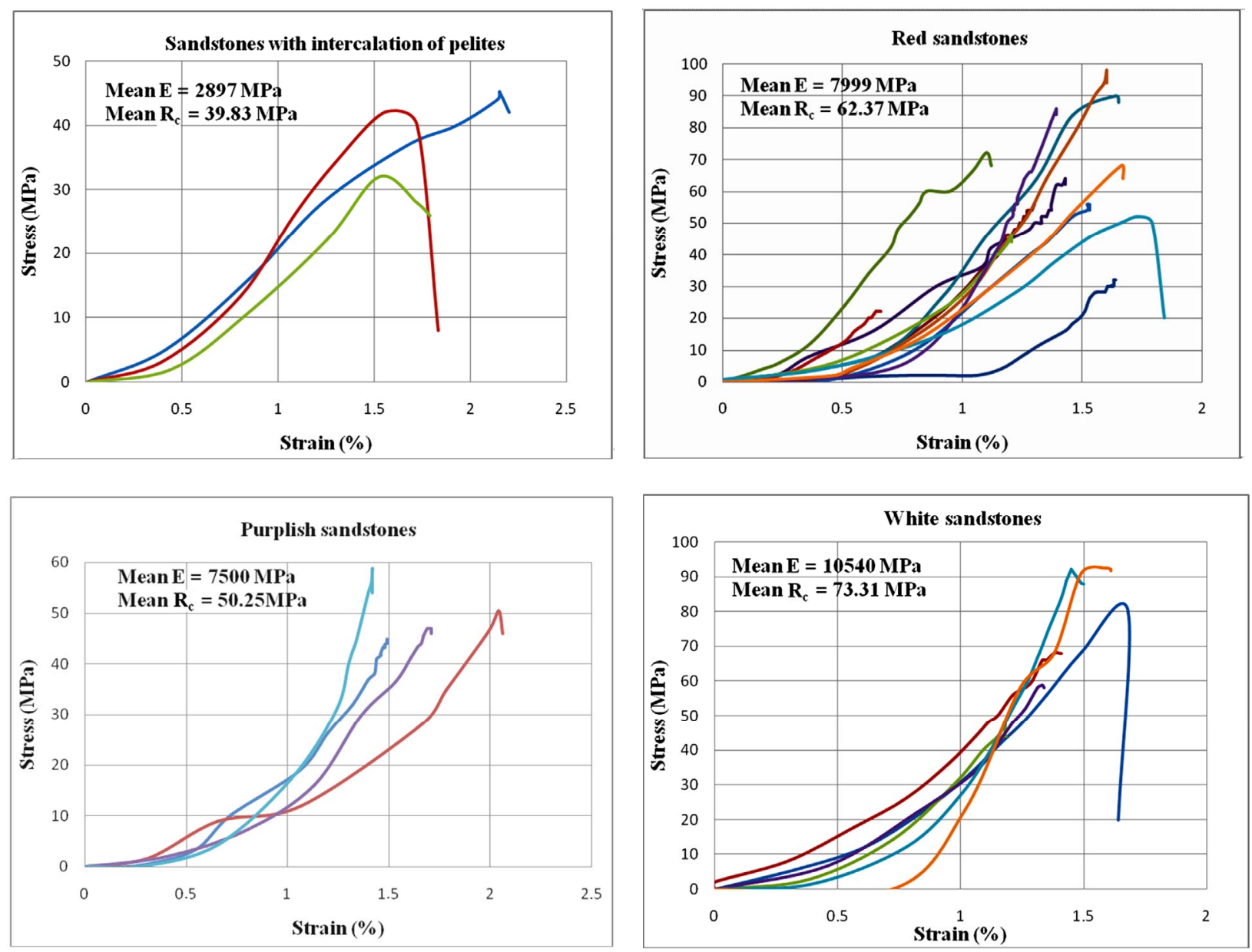

Figure 9. Strain-stress curves of the sandstones samples.

Table 5. Uni-axial compression tests results.

\begin{tabular}{lcccc}
\hline & Red Sandstones & White Sandstones & Purple Sandstones & Sandstones with Intercalation of pelites \\
\hline $\boldsymbol{E}$ (MPa) & 7999 & 10,540 & 7500 & 2897 \\
$\boldsymbol{R}_{\boldsymbol{c}}$ (MPa) & 62.87 & 73.31 & 50.25 & 39.83 \\
\hline
\end{tabular}

According to the tests results (Figure 9 and Table 5), best characteristics $\left(E\right.$ or $R_{c}$ ) are obtained for the white sandstones facies. This is caused by the fact that this facies is less rich in pelites and is constituted essentially of quartz (hard mineral). Minerals of this facies are also embedded causing their very good cohesion. Portion of pelites aren't very important in this facies also.

The second facies correspond to red sandstones. Like the first facies, this one is also characterized by embedded of the minerals, more proportion of pelites and microfractures compared to the white facies. It contains also more part of fragments of rock with granit's minerals. The third facies corresponds to the purple one. This facies shows a very important part of microfractures. Also, their smooth aspect characterizes those microfractures. The worst characteristics are obtained for the sandstones with intercalation of pelites. His high proportion of pe- lites characterizes this facies. This confers them very low uni-axial compressive strengths and Young moduli.

\section{Slope Stability of the Cliff}

\subsection{Analysis of Dip and Poles of Discontinuities}

Analysis of maps of dip direction (Figure 11) and diagram densities (Figure 10) show that:

- In Walidiala $\left(\mathrm{S}_{1}\right)$ the discontinuities are concentered in all the area of the stereogram. Dip directions are low and sens of pandage are variable. In Tanague $\left(\mathrm{S}_{2}\right.$ and $S_{3}$ ), poles of discontinuities show concentrations along the E-W axe and the dip direction sense are East, W, NNW and NE.

- The side between Dindifelo and Pelel Kindessa $\left(\mathrm{S}_{4}\right.$ to $\mathrm{S}_{6}$ ) shows three discontinuities families. The first one is oriented NNE-SSW, the second one NE-SW and 
the third one in E-W. It shows high dip preferentially in ENE but also in N and SE. The side between Dindifelo and Segou $\left(S_{7}\right.$ to $\left.S_{10}\right)$ shows the same concentration with dip direction essentially on the NNW and ENE. From Afia II to Segou $\left(S_{12}\right.$ to $\left.S_{15}\right)$, discontinuities show same the characteristics. Dip directions are NNE and SSW.

- The side in front of Segou $\left(\mathrm{S}_{16}, \mathrm{~S}_{17}\right)$ shows three families of discontinuities. The first family is concentered $\mathrm{N}$ with dip direction sense in the $\mathrm{N}$ and in the $\mathrm{S}$. the poles of the second family are concentered NNW with dip sense to the NNW and SSE. The poles of the third family are concentered to East with dip directions to N, S, SSW, WNW and WSW.

- The side in face of Yamoussa $\left(\mathrm{S}_{18}, \mathrm{~S}_{19}\right)$ shows also three families of discontinuities. The first one shows concentration of pole to the SW with dip direction to the NE. The poles of the second family are concentered to NE with high dips to the SW. The third family shows a concentration of poles of WNW and their dip directions are oriented into ESE to WSW, $\mathrm{N}$ to $\mathrm{NE}$ and SE.

\subsection{Slope Stability of the Cliffsides}

This section studies the unstable possibilities of rocks by stereographic method (Figure 12). For this, all fracturations crossed are represented in a stereogram. So, for this analysis, we must have the orientation of the cliffside and of the bedrock.

The area of Walidiala shows possibilities of dihedral and plane sliding. These slides have done to SE sense $\left(S_{1}\right)$. In Tanague $\left(S_{2}\right.$ and $\left.S_{3}\right)$ there are possibilities of dihedral sliding to WNW associate to switching instabilities to NW. The side between Pelel Kindéssa and Dindifelo shows possibilities of dihedral sliding into the WSW, East and NNW $\left(\mathrm{S}_{4}\right.$, Figures 10-12). The side $\mathrm{S}_{5 ; 6}$ show possibilities show also a possibility of plan sliding and dihedral sliding. The Cliffside between Dindifelo and Segou shows switching instabilities associated to Tipping rock. These instabilities have done into N to NW.

Between Segou and the cascade of Segou we have possibilities of plane instabilities associate to dihedral instabilities. These displacements have done into the $\mathrm{N}$ and the NW $\left(\mathrm{S}_{11}\right.$ to $\mathrm{S}_{14}$, Figures 10-12). The side on face to Segou ( $S_{15}$ to $S_{16}$, Figures 10-12) shows the possibilities of instabilities are represented by switching, dihedral and plane sliding. Concerning the Yamoussa side $\left(\mathrm{S}_{18}\right.$ to $\mathrm{S}_{19}$; Figures 10 and 11), instabilities are represented by dihedral, plan sliding. There are also possibilities of stipping of rock.

\section{Conclusion}

Previous studies allow us to conclude that the area of Segou is characterized by discontinuities and microdiscontinuities forming three families. These families are oriented NNW-SSE, NE-SW and ENE-WSW. Finest studies of this Cliff show the sandstones and pelites are crossed by discontinuities. These formations show variables values of $J R C_{n}$. These values of JRC are low for fractures, microfractures and surfaces of pelites beds. For

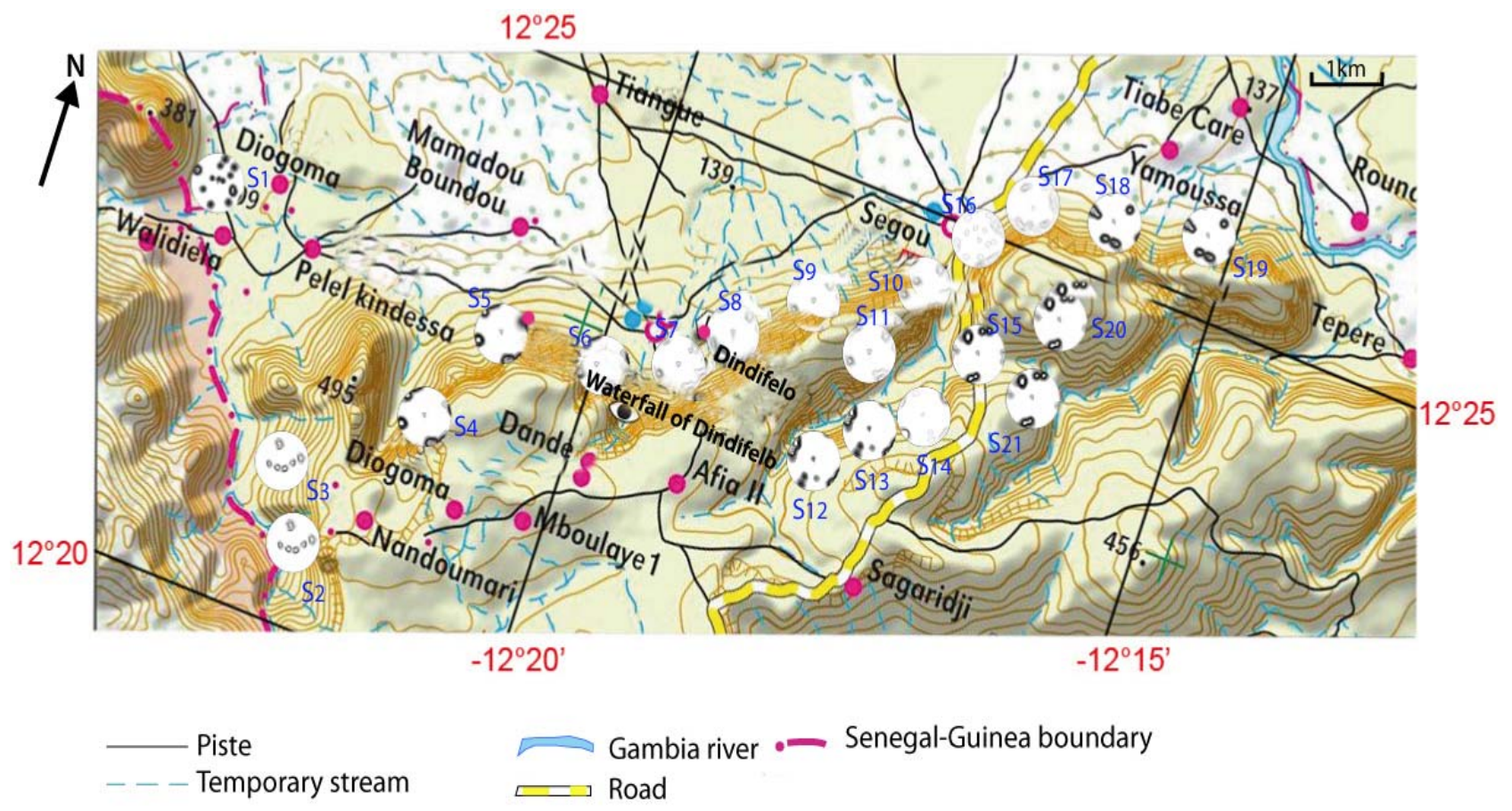

Figure 10. Densities of pole map of discontinuities. 


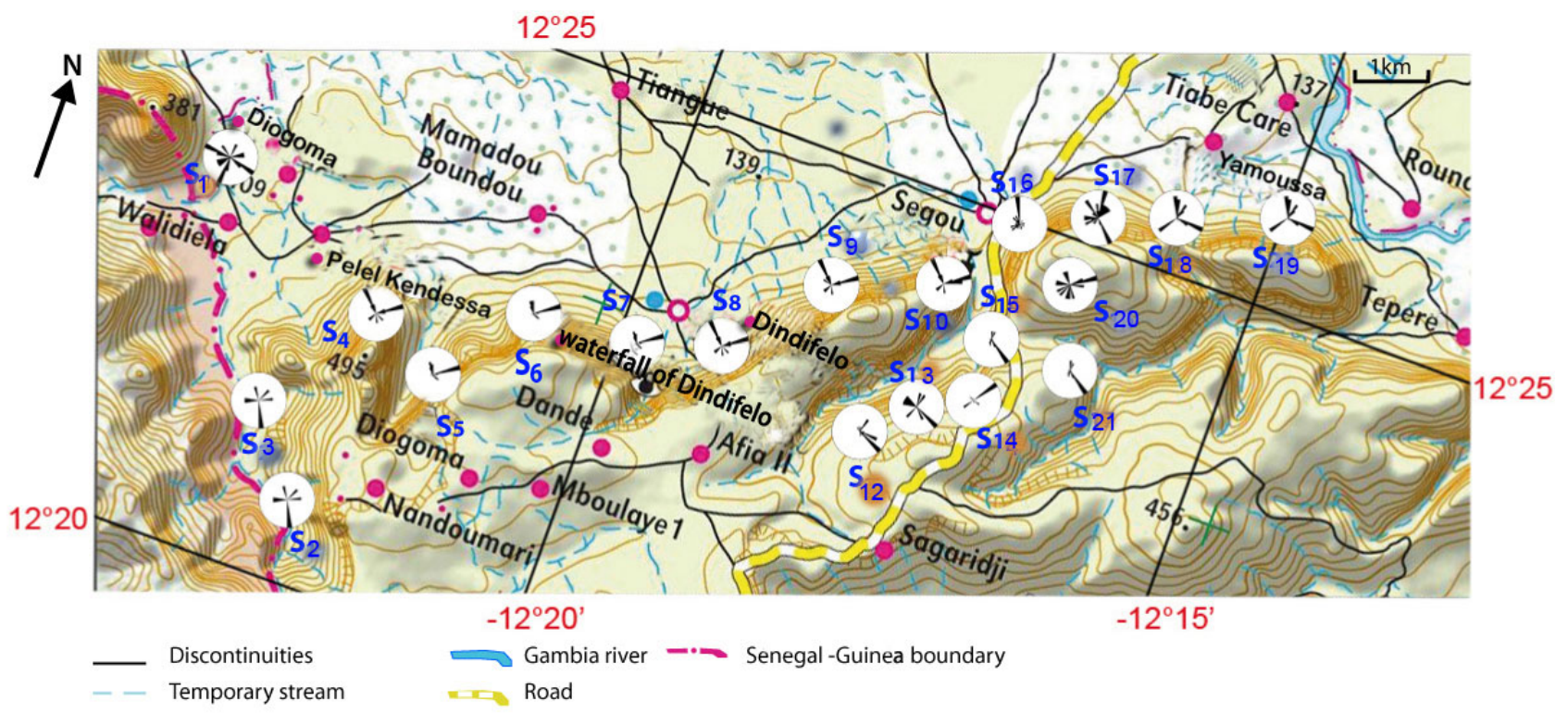

Figure 11. Dip direction map of discontinuities.
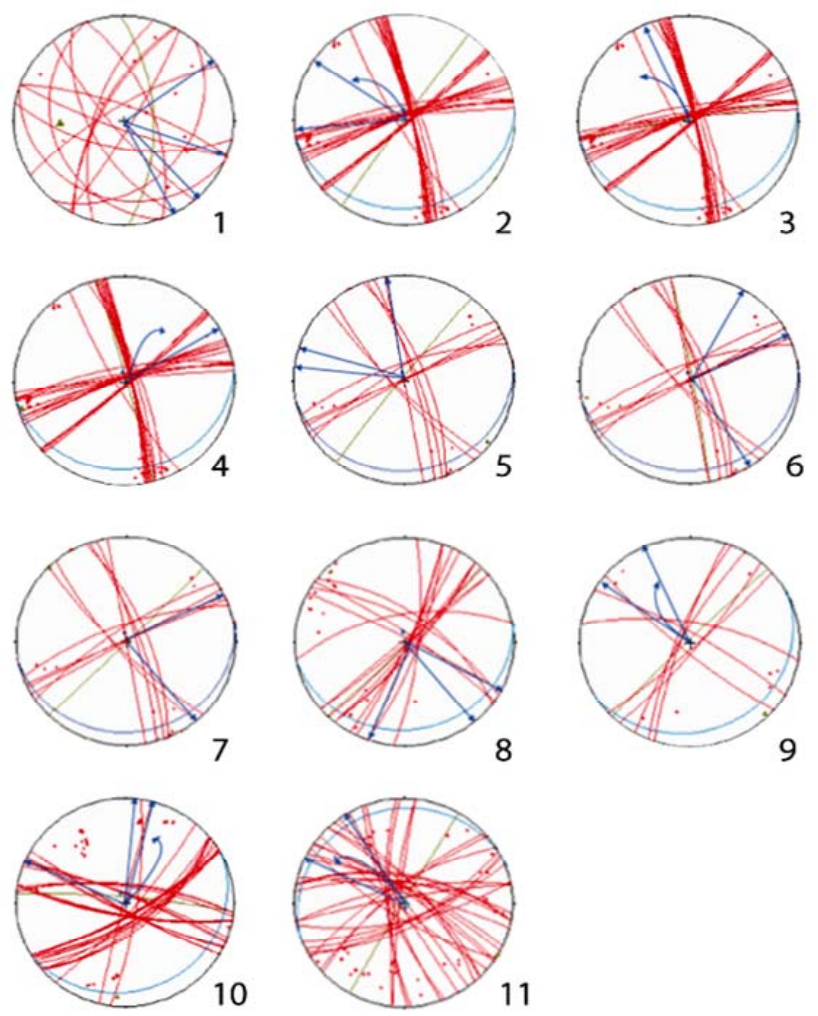

Figure 12. Stereographic plots of discontinuities cross on different hillsides.

the surface of sandstone beds and the contacts between quartz minerals, there are high values for JRC. The uniaxial compression tests done on to different facies of sandstones shows these mechanical parameters (Young modulus and Uni-axial compressive strength) vary from the white sandstone to the sandstone with intercalation of pelites. The greatest values are obtained for white sand- stones which are less rich in pelites. The second one is the red sandstone also clean but with most important part of pelites than the white one. Purple one, very fractured, represents the third facies. The facies with worst characteristic corresponds to the sandstones with intercalation of pelites. The Young Modulus and Uni-axial compressive strength decrease with the proportion of pelites and 
also with the microfractures. The cliff shows a very complex instability with sliding plane and dihedral associate to switching.

\section{Acknowledgements}

Authors would like to Acknowledge Mr. Amsata Thiam, technical Director of SENBUS industries sa for his great contribution in this work, allowing to us the supplies of his manufactory for the samplings. We acknowledge also Dr. Edmond Dioh, Head of the Department of Geology of the IFAN-Cheikh Anta Diop (Dakar), most of the microscopic analysis had been done in his laboratory. The authors would like to acknowledge Mouhamadou Lamine Lo (Assistant Professor-EPT/Thiès) for his guidance and valuable input in this research project.

\section{REFERENCES}

[1] M. Villeneuve, "Etude Géologique de la Bordure SW du Craton Ouest-Africain-La Suture Panafricaine et l'Evolution des Bassins Sédimentaires Protérozoïques et Paléozoïques de la Marge NW du Continent de Gondwana,” Thèse de Doctorat, Université d’Aix-Marseille III, 1984.

[2] C. Bense, "Les Formations Sédimentaires de la Mauritanie Méridionale et du Mali Nord Occidental (Afrique de l'Ouest)," Thèse d’Ingénieur Doctorat, de l’Université de Nancy et Mémoire, 1964.

[3] J. P. Bassot, “ÒEtude Géologique du Sénégal Oriental et ses et ses Confins Guinée-Maliens,” Mémoire BRGM, 1966,
$\mathrm{N}^{\circ} 40$, p. 332.

[4] R. Trompette, "Le Précambrien Supérieur et Paléozoïque Inférieur de l'Adrar de Mauritanie (Bordure Occidentale du Bassin de Taoudéni, Afrique de l'Ouest): Un Exemple de Sédimentation du Craton,” Thèse de Doctorat d'Etat, Université Aix Marseille, Marseille, 1973.

[5] COGEMA, "Plan Minéral de la République du Sénégal,” Vol. 2, 1982, pp. 566-572.

[6] PASMI, “Cartographie Géologique du Sénégal Oriental. Carte Géologique au 1/200000, Feuille Saraya-Kédougou Est,” Notice Explicative, 2010.

[7] N. Barton and N. Choubey, "The Shear Strength of Rock in Theory and Practice,” Rock Mechanics, Vol. 10, 1977, pp. 1-54.

[8] M. J. A. Leal-Gomes, "Some New Essential Questions about Scale Effects on the Mechanics of Rock Mass Joints,” University of Trás-os-Montes e Alto Douro, Vila Real, 2003.

[9] M. Jaboyedoff, "Caractérisations Géométriques Simples des Discontinuités dans un Massif Rocheux. Quanterra," International Independent Center of Climate Change Impact on Natural Risk Analysis in Mountains Area, 2003.

[10] J. Zhao, “Propriétés des Discontinuités,” EPFL-ENACLMR, 2008.

[11] ISRM, “Technology Roadmap for Rock Mechanics," South African Institute of Mining and Metallurgy, 2003. 